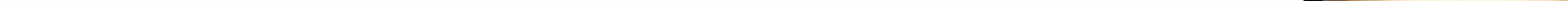




\section{Strangers no More: The Initial Hitchcock Murder}

If we compare murder scenes from distinct periods in Alfred Hitchcock's oeuvre, we find a sharp gradation in the intensity of visual depiction from the first talkie, Blackmail (1929), to Strangers on a Train (1951), and to his penultimate film, Frenzy (1972), which essentially marks the end of the director's career. ${ }^{1}$ We go from a long shot of curtains that hide the murder in the first film, to a paradoxical close-up of glasses with a small vignette reflection of the murder in the second, and we end with close-ups of the actual people, both the victim and the aggressor, in the third film. By allowing for a more direct intrusion of the camera into the traumatic experience of the victims, the director uses increasingly sadistic images in order to control the psychological responses of the audience. A structural space for the audience is thus born, as Hitchcock targets a particular reaction through "the equation victim=audience" (Clover 52). However, the violent display in the initial murder scenes of the three films mentioned above - the scenes which establish the identity of the villain - generates a potentially dominant sadistic stage that challenges the fluid dynamic between the victim, the spectators and the villain. In other words, when it comes to the original murder scene, the Hitchcock murderer does not allow the audience to move away from an active and sadistic stage.

The structure of a typical Hitchcock murder follows the Freudian psychoanalytical model, and according to Slavoj Žižek it mirrors the three stage Freudian logic of fantasy in “A Child is Being Beaten." In Hitchcock's films, the critical moment takes shape in an intermediate phase where the spectator becomes "aware of the ethical attitude contained in the villain's subjective position" (52). At the moment of denouement, when the villain is about to die, he is seen repenting. The villain becomes conflicted as to what his fate should be: should he be absolved, or punished? The audience's psychological reaction to the villain quickly evolves from sadism to compassion by way of this intermediate phase. Similarly, the Freudian fantasy scene, "A Child Is Being Beaten," has three distinct stages. Initially, the child sees that the father is beating a child who represents a rival, someone whom the observer hates; this is the sadistic phase of the sequence. It is followed by a reversal to a masochistic phase, as the child sees himself being beaten. This reversal happens when the child becomes riddled with guilt because of the initial sadistic desire from the first stage, and consequently the child wishes to be punished. The final form of the fantasy eliminates the active subject who does the beating, and becomes an impersonal observation: "A child is being beaten." According to Freud, the most important phase in this sequence is the second one, because it is the stage that essentially disappears; it is repressed by the child. Just as Freud uses the repressed memory of the second stage to give this particular fantasy its necessary flow, Žižek points to an intermediate, transition stage in Hitchcock's construction of the murder scene. However, Žižek's model only refers to the final resolution of the film. A separate model - one that also simplifies the rigid Freudian model - is needed for the initial murder scene.

The examples used by Žižek - Oscar's murder in Sabotage (1936), the fall from the Statue of Liberty in Saboteur (1934), and Gromek's murder in Torn Curtain $(1966)^{2}$ - refer to sadism, but the main focus is elsewhere: "our thesis is that Hitchcockian murders [...] are governed by a homologous fantasy logic. The first phase is always "sadistic"; it consists in our identification with the hero, who finally has the opportunity to have done with the villain. [...] The final phase is, of course, the compassionate inversion" (50). In the initial murder scenes, the first phase is also always sadistic, but the audience is forced into an identification with the murderer, rather than the victim. Furthermore, while Žižek's argument is insightful, I believe that he uses the wrong word - murder when talking about those scenes. If Žižek's argument holds true, and both the victim and the aggressor desire the same thing, then these are murder-suicides, rather than just murders. More importantly, Žižek implicitly assumes 
that spectators will respond uniformly. Psychoanalytic film theory has too often homogenized an audience that in fact elicits distinct responses to the action on screen.

In her book Men, Women and Chainsaws, Carol Clover discusses at length the question of the audience's identification with characters in horror films, and contends that the genre is mainly victim-identified (8). She does, however, consider this to be a recent trend, as opposed to earlier violent depictions in cinema that "allow for a large measure of spectator identification with the rapist," (152) like in Frenzy, to which we will return later. There are a lot of nuances to Clover's argument, as she traces a shift in identification from the killer to the character she calls the "Final Girl" - the last female character not to be murdered, and who usually turns the tables on the killer (45-46). According to Clover's research, horror films are meant to gratify a predominantly male audience, but she finds that even the men incline toward an association with the Final Girl rather than toward the typical male agent of these films, the killer. In a response to Raymond Bellour's reading of Psycho, Janet Bergstrom claims that the issue of identification needs to be complicated. Her stance is that "spectators are able to take multiple identificatory positions, whether successively or simultaneously" (58). Bellour himself, actually, believes that a film's meaning and its effect on the audience do not depend on a stagnant structure, but rather on an unpredictable, dynamic system (26). The text of a film can yield multiple interpretations, and the reactions of the audience are equally fluid in this equation.

However, the most important problem with this particular Žižek model is that it only works in the context of the final moments of the film. At the denouement of his films, Hitchcock usually closes the Oedipal cycle by offering the audience the satisfaction of seeing the villain die. From this perspective, Hitchcock's films inscribe themselves perfectly in the typical doctrine of classic Hollywood cinema, which eliminates the disruptive element and re-establishes order at the end of the film. Yet, the initial murders do not follow the same fantasy logic. Instead, they act as catalysts for the sadism that the audience takes on during the first fantasy stage mentioned above. More significantly, those scenes push the limits of the audience's capacity for sadism within that particular moment. The initial murder scenes in Hitchcock's films do not have multiple stages; instead, the audience has to contend with a continuous, sadistic phase one. Elements of sympathy occur throughout the films, but they are irrelevant during the initial murder sequences (which usually happen early in the films, before the depth of the characters is established). In this sense, the spectators are not allowed to associate with the victims, and thus assume a masochistic position, because during the initial murder scenes we are not familiar enough with those characters.

Freud describes sadism and masochism as parts of the sexual instinct of any human being, with sadism representing the active form, and masochism the passive form. He also insists that sadism is in fact the primary instinctual aim, while masochism is nothing more than an inverted type of sadism. Lynn Chancer echoes on this dual capacity of sadism noting that "each position has the potential for transformation into its opposite" (4), and Parveen Adams considers masochism not to be a homogenous field (33), just as the responses of audiences do not usually coalesce into one category. The ambivalent relationship between sadism and masochism is best exemplified by the character of Alice from Blackmail, who in the span of minutes oscillates from victimhood and masochism to an active role of violence and sadism. However, she reverses to guilt and masochism after the murder. Sadism implies a level of aggressiveness that Alice does not possess, but rather the two other murderers that will be discussed later. The aggressiveness comes from a wish to exercise control over external objects: "The sexuality of most male human beings contains an element of aggressiveness - a desire to subjugate. The biological significance of it seems to lie in the need for overcoming the resistance of the sexual object by means other than the process of wooing" (Freud 23-24). In the case of Hitchcock's films, that aggressiveness manifests itself toward the victims of the villains, or the pseudo-villain in the case of Alice.

172

CINEJ Cinema Journal: Vlad DIMA

Special Issue: 1 (2011) | ISSN 2158-8724 (online) | DOI 10.5195/cinej.2011.1 | http://cinej.pitt.edu 
As one of Alfred Hitchcock's first memorable protagonists, Alice represents the beginning of a long trend of female protagonists portrayed ambivalently. ${ }^{3}$ Even though Alice kills a man, because of the circumstances and her undesirable position, the audience does not necessarily perceive her as a murderer. The setup of the film is simple; following a dinner with her boyfriend, Frank, Alice meets an artist and proceeds to visit his apartment. The scene begins with a long staircase walk that the couple takes to the top floor of Crewe's building. The slow climb up the stairs and the patient camera work following the two characters emphasizes Alice's separation from the world below; entering an uncharted territory hints at the possibility of danger. But Crewe is very calm, takes the time to check his mail, talks to the landlord, and while Alice is undressing behind the screen, he plays the piano or he whistles. None of these actions point to anything out of the ordinary. In fact, an unusual reversal takes place here. Crewe's aloof actions point to masochistic behavior because a key characteristic of masochism is a suspense that "involves a delay, a waiting; it is a state with no definite end-point; it is an endless postponement of gratification" (Adams 33). The scene thus begins with the man assuming a masochistic position, which generates a mild level of sympathy towards him so that the audience does not find him threatening. But when Crewe does reveal an aggressive side, his prior actions are reinterpreted as sadistic foreplay, rather than masochism. As Alice changes behind the screen, the gaze of the spectator completes the formation of the classic voyeuristic triangle: the audience, the active male agent, Crewe, and the passive object, Alice. Since Crewe cannot see the woman, the "undressing is thus presented pornographically for the sole delectation of the film spectator" (Modleski 21). Hence the male character's gaze is not satisfied, only that of the audience. Continuing the game of manipulation, Hitchcock thus pits the villain against the spectators, as they compete for (sadistic) satisfaction.

As they walk inside his apartment, Crewe says, "I'll light the fire," a declaration that can definitely be understood figuratively. He gives her something to drink, and she reacts by saying it is too strong. In a later scene, while he completes her drawing of a head by adding a naked body to it, he makes his intentions a little clearer. She signs the sketch, approving whatever the artist had on his mind and "authorizing ... man's view of woman and thereby consenting to the silencing of her own possibly different ideas about herself" (Modleski 20). This event is underlined by Crewe's exclamation, "Hurray!" - he misinterprets the drawing as a sign that she likes him. There may be a subtext taking shape that she would agree to sleep with him. Robin Wood also points to this fact: “... her behavior in Crewe's apartment continuously suggests a desire for erotic pleasure" (262). When she asks whether she can try on the dress, Crewe says "That's an idea," making it seem like everything comes from her, that she is the one initiating things. Finally, when he backs down, turning around as if giving up, she asks "Should I really try it on?" which denotes insecurity and uncertainty about what she really wants to do. As Crewe approves and moves away, the view of the camera is blocked by his body ${ }^{4}$; and he becomes an obvious obstacle - one that Alice will have to overcome.

When Alice emerges from behind the screen, he tries to force himself upon her, and when she resists, he responds, "Don't be silly!" This is a comment consistent with her previous, childish behavior. When he drags her behind a curtain we briefly see their shadows cast on the wall, then our view is cut completely, and we only hear her cries. The shadows on the wall, rather than the human figures, flatten the two characters and dehumanize them. As the two struggle behind the curtains, the camera moves to a side angle. Then Alice's hand comes from behind the curtain, and fumbles about on a little table until it finds a bread knife. The hand retrieves the knife, disappears behind the curtain, and then the sound goes out. We know that he is going to be stabbed, but it happens quietly: no sound, no scream. The fact that the man is unable to utter a sound suggests emasculation and a loss of power, which is further emphasized by the shot of his arm hanging out from behind the curtain. The lifeless arm functions as a phallic substitute, a flaccid penis - the attempted rape has failed.

It is at this very moment that Hitchcock's ambivalence takes clear shape: Alice trades places with the man and becomes the dominant figure. When she comes out from behind the curtain, she moves in a very 
machine-like manner. She goes right, then left to put the knife back on the table, then right and left again. Her arms are very rigid along the sides and the knife she is holding is clearly fetishized. The knife in her hand supplants Crewe's flaccid phallus: Alice becomes the active, male figure, and at the same time she also transforms into a machine. She seems to trade her female identity for that of a male, but it is a very basic, animalistic sight. Her change takes the dehumanization experienced earlier through the shadows a step further. But when the camera moves in a little closer and the music comes back on, Alice shivers and covers her arms as if trying to warm up. She moves away and looks back toward the dead body with a very intense, angry look on her face. This last glance hints at the possibility that Alice can be a sadistic, active agent; she becomes the bearer of the gaze. The audience is initially offered an association with the aggressor Crewe, then briefly with Alice as the victim, followed by Alice as the aggressor. So overall, the audience is pushed toward a sadistic point of view that culminates with Alice's murder, as she ascends very quickly to the active, sadistic stage. The audience goes along with her because she turns into Carol Clover's Final Girl who embodies a blend of masculine and feminine traits (61). Alice thus becomes an androgynous character with whom both the male and the female spectator can associate, but always on a sadistic level.

The sadistic one-stage is even more clearly demarcated in the murder scene in Strangers on a Train. The plot of the film is ingenious: Bruno meets Guy on a train and proposes that he kill Guy's wife, Miriam, who would not grant him a divorce, so that he can marry his new love interest. In exchange, Guy is to kill Bruno's father. Even though Guy never agrees to the plan, Bruno still goes ahead with his part, and ends up trying to pin the murder on Guy by planting the latter's lighter at the scene of the murder. The actual sequence of the murder is rather quick, comprised of four shots and lasting only forty-two seconds. At a carnival, Miriam becomes isolated from her companions. She suddenly comes toward the camera, and she notices Bruno, who had been following her. The man's hand comes into the frame, holding the lighter from Guy, and he proceeds to light it up in Miriam's face. She answers positively to his question about her name being Miriam, which prompts him to place his hands on her neck immediately. He rotates to the left of the screen, briefly obscuring our view of the woman. The jovial background music, which complements the carnival atmosphere, underscores the sinister choreography of the scene, and amplifies the horror of the killing. Bruno's strength is emphasized because he dominates Miriam physically, but he also "controls" the film frame. The audience is directed to follow his actions, and thus assume the sadistic point of view.

Miriam's glasses are one of her defining traits, and they fall to the ground when Bruno touches her neck. Mary Ann Doane talks about the stereotype of women with glasses: "the image is a heavily marked condensation of motifs concerned with repressed sexuality, knowledge, visibility and vision, intellectuality, and desire. The woman with glasses signifies simultaneously intellectuality and undesirability; but the moment she removes her glasses, she is transformed into spectacle, the very picture of desire" (50). She continues this argument by talking about the male gaze; women who wear glasses are perceived as active lookers, they are no longer seen, but seeing. This means that such a woman can analyze, and that she is "usurping the gaze," and thus she poses another kind of threat to the male system, a threat that goes beyond the lack of penis. However, women who are capable of seeing end up being punished in mainstream cinema. Unlike Alice's situation (who has to live with the guilt), the punishment inflicted on the woman in this scene takes a more traditional, violent route.

The camera cuts to the glasses that have fallen in the grass, next to the lighter. The glasses actually fall with the lenses down, but in the next shot we see the reflection of Bruno and Miriam in those same glasses. This is a small slip on the part of the director, but the reflection is the emblematic shot of the entire film. The two characters are suddenly twice framed, once by the screen, and once by the glasses; the double frame reinforces the absolute imprisonment from which Miriam cannot escape. Both characters are deformed in the thick lenses, and 
Bruno slowly puts Miriam down, continuing a slight circular movement. As he sets her limp body on the ground, he slowly retracts his arms, and the reflection provides us with an exaggeration of his murderous hands. Before reaching the ground, Miriam's head obstructs our view of the murderer and we have an effect opposite of the one we saw at the beginning of the sequence; now the murderer disappears behind the victim. Miriam hardly makes any noise, except one muffled sound at the beginning, just as Bruno begins to strangle her. She is silenced, and in the reflection she is transformed into a monster along with the murderer himself. Before Miriam exits the double frame, for a brief moment the contours of the victim and the murderer coincide, echoing the shadows cast on the wall by Alice and Crewe. In the aggressive act of killing, both victim and villain are fused in a macabre union, a dance of death that is a photo negative of the act of love.

Nonetheless, Bruno does distinguish himself as the bad guy: the dark suit, the hat that obscures most of his face, the monstrous hands in the reflection, and of course, the cold blooded murder. Later in the film, he does exhibit an equivocal charm, and we learn about his complicated relationship with his father. While mild sympathy toward Bruno is possible, in the end the audience is manipulated toward a pure sadistic stage that follows Bruno's perverted meanderings. The progression of stages referred to by Žižek does not happen in this scene either; instead the audience is maintained in a suspenseful, sadistic state as we voyeuristically experience what Bruno goes through. We are continuously invited to share his sadistic drive, which remains the only possible stage for him and the audience.

A mental escape from the controlling sadistic stage turns out to be even more unlikely during the rape/murder scene in Frenzy. The first thing that comes to mind about Frenzy is the fact that the depiction of the murder/rape scene becomes more graphic than in the previous films. Tania Modleski notes: "In Blackmail, the difficulty is that nothing is shown ... whereas in Frenzy, too much is shown, nothing is left to the imagination" (102). While London is terrorized by a necktie murderer, Richard is wrongly accused, following his ex-wife's brutal murder. He has to prove his innocence, and in the end, he and inspector Oxford find the real criminal, Bob Rusk. The murder scene reminds one of Žižek's analyses of pornography, in which he states that it is the audience that is gazed at, rather than the other way around, because pornography bares it all, and leaves nothing to the imagination (36-37). Just like in pornography Hitchcock's audience becomes a victim of the violent murder scene, but equally important is the fact that we are forced into an association with the villain. The rape in this scene "exudes a kind of lascivious sadism with which the viewer is invited to collude" (Clover 139). The scene pushes the limits of violence and forces the spectator to have an intense connection with sadism. Not everything pertaining to the sexual realm is shown in the rape/murder scene in Frenzy, but everything concerning the actual murder is indeed shown, unlike in the previous two cases. So, in a way, this particular murder becomes the equivalent of pornographic display in the context of conventional film.

Continuing the similarity to pornography, the murder scene begins in the middle of the proceedings. Bob enters a matrimonial office run by a secondary character, Brenda. Paula Cohen argues that this scene is "particularly horrific" because of its "unmediated presentation; it lacks the kinds of narrative meaning attached to deaths in earlier films" (158-59). There certainly is not enough preparation, but that is exactly what makes this scene work so well. Brenda is putting on make-up, and Bob enters the room and immediately shuts the door, blocking it with his body. ${ }^{5}$ The action is the first warning signal that he is a villain: by blocking the exit, he traps Brenda.

The distance between the two is quickly shrunk through an alternation of point-of-view shots, and a transition from long shots to close-ups. As the audience is drawn in closer to the two characters a "shared suspense" is created. This type of suspense allows the audience to identify more with one character: "By drawing us into the intense experiences [...] shared suspense tends [...] to offer an acute insight into what it feels like to be 
on the receiving end of male violence" (Smith 20). However, instead of a masochistic position, the viewers are drawn into what it feels like to be on the aggressive, sadistic end. Brenda is unable to put up the same kind of fight that Alice does. Bob pushes her around the room, first against the wall, then grabs her ankle and places her on an armchair. When the phone rings, we see her frantically waiving her arm, gesticulating toward the phone. One of the next shots contains only her arm which emphasizes her isolation. In Blackmail, when Crewe's lifeless arm comes out from behind the curtain, it echoes a loss of power. Brenda's arm, too, becomes a symbol of her weakness.

She accepts her weakness, and surrenders to Bob's brute force, which is marked by the fact that she is willing to take her dress off. This is in fact the only small victory she pulls off in the precarious situation. Bob had said that she "was his type," which means that he wanted her to put up a fight ("I like you to struggle," he tells her). Her capitulation becomes a refusal because in the end she does not struggle, and as Modleski suggests, the women's "capitulation to male desires and expectations is never complete" (114). However, this seems like a very small victory in the grand scheme of the scene. Although the details are very graphic, Hitchcock finds an additional way of suggesting the violent progression of the sexual act. Bob repeats the same word over and over again, "Lovely," which is particularly inappropriate and horrendous, and as he approaches a climax, his voice changes in tone. The repetition of the paradoxical word ${ }^{6}$ creates an absurd counterpoint to the dreadfulness of the scene, which echoes the incongruous music in the Strangers on the Train murder scene.

As Bob is catching his breath, the camera makes the last move, getting in as close as possible to the two characters, but also isolating them in individual close-ups. For a brief moment we think that the scene is going to end, but when Bob utters, "Women, they're all the same," we realize it will continue. The murder scene is rapidedited through a lot of cuts that show either Bob's face, the knot of the tie on Brenda's neck or her head moving frantically. The mixture of shots underlines the fact that the scene develops rather fast. The climactic effect of the rape/murder scene in Frenzy is in part due to an editing technique meant not only to freeze the spectators in their seats, but also to manipulate them in whatever direction Hitchcock deems necessary. Once again, as in the shift in Blackmail, the audience finds itself in the position of victim and aggressor simultaneously. While the rape scene is shot from a side, with no shot-countershot alternation, the murder scene changes points of view several times, confusing the audience caught in the middle of the onslaught. Whatever feelings of sympathy the spectators experience for Brenda, they are stifled by the power of the violent act. We move into a large close-up of her eyes, and for a moment the shot stops in a freeze-frame - she is dead. The quick freeze-frame is an interesting choice because the film itself "dies" for a fraction of a second along with the actual victim. The audience is given a very brief moment to catch its collective breath, as we are taken out of the diegesis.

The last shot of the victim shows her with her tongue out in a large close-up; she is sprawled out on the armchair, arms apart in a crucifixion position, and the pendant cross on her chest glimmers. The tongue functions as yet another lifeless appendix, like Crewe's arm. At this specific moment, the music comes back into play, adding a little more effect to this horrifying image, but completely pulling us out of the scene and out of the association with both the victim and the murderer. The music has a soothing effect, but the damage is done - this scene accomplishes what it is meant to: it is one of the most disturbing scenes in cinema. Furthermore, it marks Hitchcock's victory - the disturbed, torn subject in the audience gives in to the grotesque. 


\section{Conclusion}

The level of aggressiveness during the three murders vastly increases from Alice's unseen murder of Crewe to Bob's graphic rape and strangulation of Brenda. Along the way, the audience does not necessarily follow the psychological stages of the Freud/ Žižek fantasy model, because in spite of Hitchcock's attempts to manipulate the audience through a range of sentiments, the increasingly sadistic stage and images that emerge during the ferocious killings overwhelms our psyche in the end. Traces of sympathy occur seldom, and it is much later in the films that repentance does or does not happen, along with the appropriate compassionate reaction from the audience. In the meantime, we are left to negotiate with our own ambivalent feelings and to search for a way out from the painful (and maybe pleasurable) identification with the Hitchcock villain with whom we are strangers no more.

${ }^{1}$ Hitchcock's last film, Family Plot (1976), is considered by many to be a failure.

${ }^{2}$ Obviously, the schematic Žižek model was not meant to hold up for all Hitchcock films. However, I think it is important to distinguish between the murders that happen at the end of the films, and the ones that jumpstart the plot. The initial murders follow a more common path, one laden with ambivalence, wavering sympathy, but ultimately dominated by sadism.

${ }^{3}$ The ambivalence that surrounds the Hitchcock villains has fuelled the debate over whether Alfred Hitchcock is a misogynist. Although Tania Modleski does admit to a "thoroughgoing ambivalence," she also observes, "Hitchcock is often viewed as the archetypal misogynist, who invites his audience to indulge their most sadistic fantasies against women" (17).

${ }^{4}$ This a technique used by Hitchcock more consistently later, in Rope (1948). It suggests a complete, albeit momentary, visual monopoly over the shot or the scene of a certain character.

${ }^{5}$ Blocking exits is reminiscent of $\underline{39}$ Steps (1935) and even Blackmail.

6 This word is also used by inspector Oxford to describe his wife's horrendous dinner, so there is a doubleentendre at work here; "lovely" has both positive and negative connotations.

\section{References}

Adams, P. (1996). The Emptiness of the Image. Psychoanalysis and Sexual Differences. London: Routledge.

Bellour. R. (2000). Analysis of Film. Indianapolis: Indiana University Press.

Bergstrom, J. (1979). Enunciation and Sexual Difference. Camera Obscura, 3-4.

Chancer, L. (1992). Sadomasochism in Everyday Life: The Dynamics of Power and Powerlessness. New Jersey: Rutgers University Press.

Clover, C. (1992). Men, Women and Chainsaws. New Jersey: Princeton University Press. 
Cohen, P. (1995). Alfred Hitchcock: The Legacy of Victorianism. Lexington: University of Kentucky Press.

Doane, M. A. (1990). Film and the Masquerade. In P. Erens (Ed.), Issues in Feminist Film Criticism. Bloomington: Indiana Press University.

Freud, S. (1995). Basic Writings. New York: Modern Library.

---.Three Essays on the Theory of Sexuality (2000). New York: Basic Books.

Modleski, T. (1988). The Women Who Knew Too Much. New York: Methuen.

Morris, Chr. D. (2002) The Hanging Figure. On Suspense and the Films of Alfred Hitchcock. Westport: Praeger Publishers.

Penley, C. (1989). The Future of an Illusion. Minneapolis: University of Minnesota Press.

Spoto, D. (1976). The Art of Hitchcock. New York: Hopkinson and Blake.

Truffaut, F. (1983). The Definite Study of Alfred Hitchcock. New York: Simon \& Schuster.

Wood, R. (1989). Hitchcock's Films Re-Visited. New York: Columbia University Press.

Žižek, S. (1986). Hitchcock. MIT press: October, 38.

--- (1989). Looking Awry. MIT press: October, 50.

Vlad Dima teaches at Union College and has taught French and Film Studies at the College of William \& Mary. His main research explores the aural narrative planes created by unorthodox manipulations of sound in cinema, particularly in the trans-national context of French and Senegalese cinemas. He has published or has articles forthcoming on Anne Hébert, Tom Ford, and on various issues of sound in the films of Quentin Tarantino, DjibrilDiop Mambety, and Jean-Luc Godard. 